\title{
A Guidance Document for Kentucky's Oil and Gas Operations
}

\author{
Quarterly Report \\ April 1 - June 30, 1997
}

Work Performed Under Contract No.: DE-FG22-94MT94006

\author{
For \\ U.S. Department of Energy \\ Office of Fossil Energy \\ Federal Energy Technology Center \\ P.O. Box 880 \\ Morgantown, West Virginia 26507-0880 \\ By \\ Kentucky Division of Oil and Gas \\ PO Box 14090 \\ Lexington, Kentucky 40512-4090
}




\section{Disclaimer}

This report was prepared as an account of work sponsored by an agency of the United States Government. Neither the United States Government nor any agency thereof, nor any of their employees, makes any warranty, express or implied, or assumes any legal liability or responsibility for the accuracy, completeness, or usefulness of any information, apparatus, product, or process disclosed, or represents that its use would not infringe privately owned rights. Reference herein to any specific commercial product, process, or service by trade

name, trademark, manufacturer, or otherwise does not necessarily constitute or imply its endorsement, recommendation, or favoring by the United States Government or any agency thereof. The views and opinions of authors expressed herein do not necessarily state or reflect those of the United States Government or any agency thereof. 


\title{
"US DOE PATENT CLEARANCE IS NOT REQUIRED PRIOR TO PUBLICATION OF THIS DOCUMENT"
}

\author{
TECHNICAL PROGRESS REPORT \\ June 30, 1997
}

During this quarter, the document entitled "A Guidance Document for Kentucky's Oil and Gas Operators" received final review and editing. Several copies were printed and provided to interested oil and gas operators by mail, through industry meetings and by the Oil and Gas Division inspectors.

During the final draft reviews of the document, numerous comments were received to expand the document, including sections on Underground Injection Control (UIC), as regulated by the United States Environmental Protection Agency (USEPA). The inclusion of an addendum section for operators of UIC wells will provide needed information for satisfying compliance requirements. The Division made a request for a one-year nocost extension to complete the addendum section. The request was approved by the United States Department of Energy for the one-year extension.

A formal request was made to the Region IV office of the United States Environmental Protection Agency (USEPA) to assist in the development of this addendum section. The Region IV office of the EPA has indicated their willingness to assist with this document. The UIC addendum section will enhance Kentucky operators' ability to operate in compliance with federal rules and regulations. During the next quarter, their office will be contacted to begin a discussion for development of this new section. 